\section{Transgression as Creative Freedom and Creative Control in the Media Production Classroom}

\author{
Renee Hobbs*
}

\begin{tabular}{ll}
\hline Received: & 12 September 2018 \\
Revised: & 11 November 2018 \\
Accepted: & 16 December 2018 \\
ISSN: 1307-9298 \\
Copyright @ IEJEE \\
www.iejee.com
\end{tabular}

DOI: $10.26822 /$ iejee.2019349245

\begin{abstract}
When students have the freedom to use digital media to create, communicate and disseminate messages, transgression occurs. In this paper, I situate in-school youth production in the context of pedagogical theories of participatory culture, art education, and digital and media literacy education. Using interviews with four experienced high school media production educators, I examine how educators perceive school situations where behavior or student media work products disrupt or transgress expectations. Teachers experience student transgression as an essential dimension of the dialectic between creative freedom and creative control. They perceive creative control to be a negotiation between students and teachers on issues of content, format, production and distribution processes. Teachers conceptualize the distinctions between students who use transgression as a form expressive creativity, a reproduction of the tropes of mass media and popular culture, the result of novices making mistakes as part of learning, an attempt to gain social power and status among their peers, or a challenge to adult authority. Teacher reflection on creative control and creative freedom may inform the design of media production learning experiences.
\end{abstract}

Keywords: Adolescence, Media Education, High School, Teachers, Video Production, Transgression, Media Literacy, Digital Literacy, Curriculum and Instruction

\section{Introduction}

Media, writing and art teachers ask students to reveal their hearts and minds, and in doing so, students may pay homage to their favorite movies or TV shows, mimicking YouTube celebrities like Pewdiepie or other aspects of the absurd adult world around them. Some teachers may wonder how to distinguish between imitation and more genuine self-expression. Because media culture includes a variety of forms of transgression, including political transgression, taboo topics and blurred boundaries, young people are also likely to reproduce and enact behaviors that may make their teachers very uncomfortable (Buckingham, 2002). For example, impromptu performance play in front of the camera may lead to clowning, mock fighting, enacting gender or racial stereotypes, and other forms of transgression, including potentially dangerous behavior, like making chemical explosions, filming from rooftops or using prop guns (Buckingham \& Sefton Green, 1994).

Educators who enable student creative expression navigate complex issues of both creative control and creative freedom. This research explores complex situations when educators encounter student voices that express reprehensible values or draw lines related to social values as they decide whether (or how much) tolerance for political incorrectness is appropriate. As laptops, cell phones and free or inexpensive digital tools make it easier and easier for all students to bring their voices into the classroom, creating media is becoming more and more a part of everyday school life.

In this paper, I situate in-school youth media transgression in the context of pedagogical theories of participatory culture, art education, and digital and media literacy education. Using case studies and interviews with four experienced high school educators whose students create media in the classroom, I examine forms that transgression takes in the context of school-based media production, examining how educators perceive situations where student behavior or student work products are transgressive. I examine how teachers conceptualize the types of transgressive student behavior they may experience. Some students transgress when they offer an intentionally critical perspective on contemporary culture and others may use transgression as a form of cheap thrills, distraction, self-entertainment or as an attempt to gain social power and status among their peers. From this study of experienced educational practitioners, this paper reveals insights on how media educators address issues of creative freedom and creative control in responding to the kinds of transgression they encounter when students make media in school. As the rise of mobile media brings opportunities for media production learning experiences to all learners, and not just those students enrolled in video production classes, this study offers insights on the design of media production activities and the spirit of reflection and metacognition needed for educators in negotiating power relationships in the classroom.

\section{Literature Review}

A growing literature in digital media and learning situates student media production as a powerful pedagogy that motivates and engages learners while developing key competencies in literacy, collaboration, problem-solving and creativity (Bennett, 2008; Buckingham, 2013; Buckingham \& Willett, 2013; Ito et al, 2007) There are several ways this work has been conceptualized in the literature through the paradigms of connected learning, youth media and media literacy education. Focusing on young people's out-of-school and largely informal play and engagement with digital media, Ito et al (2013) celebrates interest-driven learning. As students participate in digital learning ecosystems, they learn by hanging out, messing around, and geeking out with digital media. In dozens of case studies about teens using digital media in and out of school, however, very few examples of transgressive youth media production are found. Indeed, student creative work reported on in the many ethnographic case studies funded by the MacArthur Foundation- including Harry Potter fan fiction communities, learning to code, and video production in and out of school -- seems quite virtuous (Jenkins et al, 
2007; Ito et al, 2009a). Students are positioned as self-directed, independent learners who, with appropriate guidance and support from mentors, create media as a natural part of the learning process (Ito et al, 2013). But other researchers have problematized youth media production and identified a variety of motives that may contribute to transgression in youth media. Studies of participatory culture do include "thick description" of transgressive incidents, but the overall focus is on the positive outcomes and involvements of the media work, as if the transgressions were exceptions or "hazards" that "go with territory" rather than a near inevitability borne of developmental and discursive power struggles.

Transgression as the Reproduction of Media and Popular Culture

Because children and young people grow up in a world where transgression is plentiful in popular culture, it may seem rather normal to create videos that depict humiliation, conflict, shame and pain through representing physical or symbolic violence, including the use of racial, gender or ethnic stereotypes or "othering." Because media culture includes a variety of forms of transgression, including political transgression, taboo topics and blurred boundaries, young people may to reproduce and enact behaviors that may make their teachers very uncomfortable. When engaged in media production activities, students may pose as fighters or display their bodies in sexually stereotyped ways. They may stage chase or fight scenes or develop narrative plots that include potentially dangerous action They may use parody to make fun of teachers, parents and other authorities.

When students create parodies of media and popular culture, researchers have found that high school students may mock both the cultural products they see in the mass media and the realities and paradoxes of school life (Buckingham \& Sefton-Green, 1994). Inversions of gender and power can be seen as particularly transgressive in the context of school. In particular, researchers describe media production activities as sites where students push up against the boundaries of acceptable school behavior. In one class, a group of girls created a mock magazine they called Slutmopolitan, which parodied the magazine Cosmopolitan. In describing the project, one of the girls identified a "tart" as, where "the lipstick is the cheapest thing going, apart from herself that is" (pp. 196-197). They even included a photograph of one of the girls simulating ora sex with a chocolate bar, with text that read, "30\% extra. Only the biggest will do" (p. 198).

Clearly, pleasure and power intersect as people interact with media and popular culture. In one British school, students developed a parody for a horror film trailer involving a serial killer, in which a 16-year-old girl located the killer's motivation primarily in his gender, age, and ethnicity. The killer was Spanish, prejudiced against the English, and considered helpless elderly women to be expendable. Thus, the film involved a heady brew of gratuitous violence, xenophobia, ageism, and misogyny, all of which flew in the face of political correctness (Bragg, 2000). Such examples of transgressive creative media are not uncommon. Children's out-of-school play includes parody, gender play, and violence that builds upon, extends and subverts television advertising, movies, videogames, music and popular culture (Marsh, 2005).

\section{Transgression as a Threat to Adult Power}

As educators explore the use of media production in school, they may not be fully prepared for the issues of control that are activated as students engage with the content and format of the messages they create. Students are, of course, legally and ethically responsible for the media messages they create. But decisions about how much creative control to give students depends upon the instructor's pedagogy, values and their level of trust in their students (Darts, 2004; 2006). Faculty judgment about the appropriateness of the content of a student media production may leave the instructor's employment at risk. In some school districts, video productions are subject to district policies that state clearly that video in the classroom "shall be weighted against the value of the academic time it consumes," and that scenes that contain "vulgarity, indecency, nudity, and/or excessive violence are strictly prohibited in the classroom and school" (Saxton, 2007, 41).

One can hardly be surprised that adolescents create transgressive media as a way to gain social power over adults. When children and adolescents are constantly under pressure to conform to adult demands, their own culture becomes one of resistance inane, risqué, scatological, and politically incorrect (Mitchell \& Reid-Walsh, 2002). Adolescence is a time of sturm and drang, when strong emotions and a desire for immediacy and direct experience contributes to increased risk-taking, including resistance to the traditional authority relationships that are always present in school.

Youth may use media production activities to comment on or challenge established power relationships between teachers, school administrators, parents or other adults. For example, iln analyzing a youth media production sponsored by a development agency in Latin American, researchers found substantial disconnect between the goals of the adult leaders of the program, who wanted to create a documentary about a water program for the community, and the participating youth, who were more interested in problematizing the politically-correct power relationships between the development agency and the local community through narrative production (Hauge, 2014). In observations of elementary students media making, Grace and Tobin (2002) observed that students played with "the boundaries of language and ideology and enjoy collective transgressive pleasures" (196) when they included scatological references, racial caricatures, hurtful language and forms of cruelty that reflect the Bahktinian carnivalesque (1984) when power relations are inverted. Grace and Tobin (1998) provide many examples of such parodies from third graders. These include short videos of children enjoying "butt jokes" singing off key, and performing silly antics. The children constructed visual stories involving disastrous school field trips with "tyrannical teachers, ridiculous rules and rebellious students" (49). The videos were later watched where "performers and audience were fused in a surge of camaraderie, a spirit of oneness joined by laugher" (42). Similarly, Burn and Durran (2006) observed students video editing who laced their dialogue with social chat and outrageous humor, including the witty dismissal of pretension among teachers. Hoeschman and Poyntz (2013) note that media literacy educators must be sensitive to the affective dimensions of youth media production while being careful not to excuse the "morally and ideologically objectionable practices" that can occur when students create media (135).

Nearly all of the literature on student media production and transgression has come from anecdotes reported in case studies. Interviews with media production teachers have not yet been used to gather insight on teacher perceptions of the various forms of "inappropriateness" in video production classes in elementary and secondary education. Sometimes inappropriateness may stimulate and inspire student creativity and collaboration and other times it may be disruptive, hurtful, mean and even dangerous. How do media teachers make sense of transgression when it occurs? 


\section{Methods and Context}

In this exploratory study, four high school teachers, all of whom teach media production, were asked to respond to questions to better understand their definitions of "inappropriate" behavior and media content in the context of their classrooms where student media productions are being created. Adopting a perspective of critical realism (Bhaskar, 1997/1975) I assume the existence of a world that is independent of other people's perceptions but I recognize that their worlds are accessible only through subjectivity. As Edwards and Holland $(2013,22)$ point out, "even if reality and structures are not fully available to people, researchers can still grasp them by working from interviewees' accounts of their understandings and experiences in dialogue with theories about what social reality is like and how it works."

Participating teachers included two men and two women who were solicited from the author's social network. They include three highly experienced teachers and one in his first year of teaching. One teacher works in a public school in a largely Caucasian, middle-class suburban community, while three teachers work in public or charter schools with racially diverse students including African-American and Latino students. Participating teachers came from different educational backgrounds including independent filmmaking, business and television and cable broadcasting. As is typical of $85 \%$ of American urban schools (Hrabowski \& Sanders, 2015), the teachers in this study are white and middle-class, between the ages of 30 to 55. Pseudonyms are used to protect teacher anonymity and confidentiality.

In order to gather information about their experiences in the classroom, I also asked teachers to give examples of inappropriate behavior and explain why they believed that students engaged in inappropriate behavior or why they created media with inappropriate content. Finally, I wanted to understand how teachers respond to situations where inappropriate behavior or video content occurs. I specifically asked, "How have you handled particular situations where students engaged in inappropriate behavior or produced inappropriate video content? Can you describe a situation that you handled "well"? Can you describe a situation that you handled "poorly"?

Teachers responded to these questions in writing and in some cases, additional information was provided through responses to follow-up email queries. Because there are no constraints on location, the email interview offers some advantages as participants can be widely geographically separated and can participate in the process asynchronously. An important advantage to e-interviewing is that both the researcher and the participant have time to reflect on the responses, and as Jamie Lewis notes, "a written email response 'allows participants greater scope to think about any questions asked and, as such, often encourages more descriptive and well thought out replies' (Lewis 2006, as quoted in Edwards and Holland (2013, p. 51). However, because participants used written text, it might have led to a less spontaneous account than if other interview methods were used. In considering the sensitive nature of the topic spatial separation might also have reduced the possibility of embarrassment. Below I summarize the individual responses of the teachers, followed by an analysis and examination of three key themes.

\section{Findings}

Susanne's Perspective on Transgression

Susanne is a high school video production teacher in a suburb of a large Midwest city, working with racially diverse African-American and Caucasian students from mostly middle- and working-class students. Susanne's students produce a daily newscast as part of their coursework. Her concerns about students' inappropriate behavior centers on their freedom of movement during the production process, as students are able to move freely about the school to record their video packages. She explained that sometimes, students use video cameras as a "hall pass" to leave the room and not to complete their assigned production work: this is unacceptable behavior. Also, she notes that occasionally, students abuse their power as videographers by interrupting the flow of school life. For example, some students have entered another teacher's class to record without permission. She has also experienced inappropriate student behavior when students' interpersonal conflicts cause a delay in the production process and when students use their cell phones to play video games during class. She has had situations where students produce inappropriate content, which she defines as "anything that is seen or heard on video that is not appropriate for the target audience, the students and staff at a public high school." Cursing, gang-related gestures, and the use of explicit lyrics in songs, including those that have been "bleeped out" are examples of content she considers transgressive. Content that depicts evidence of recording in an area without permission (the gym, theater, etc.) is also a problematic for her.

Susanne is aware that when her video production students make mistakes, their errors can sometimes be visible to the whole school community. She explains:

They are under the age of 18 and are learning. They make mistakes as they go along. Mistakes are part of the learning process. Sometimes the mistakes my students make bother other teachers, but they don't bother me. The video production classes are like fishbowls. Every teacher is able to see into the bowl when a video airs. Those teachers, however, get to close their doors and teach and the mistakes they or their students make are never visible to the rest of us.

When asked why students engage in inappropriate behavior, Susanne explains that in general, students are testing limits "because they like to see what they can get away with" and because they are immature. At this age, Susanne notes, students don't always understand that behavior choices result in consequences. There have been many times where Susanne has had to handle situations where students engaged in inappropriate behavior or included inappropriate video content. When possible, and if there isn't criminal activity involved, she tries to use situations as teachable moments and she does not resort to assistance from school administrators. Instead, she talks through and explains the choices and consequences of that student or the student group's situation.

For example in one instance, students created a segment they called, "Party Boy," which featured students acting goofy in the hallway. The piece was set to music and was clearly designed to amuse and impress their peers. Susanne told students that the video was not school-appropriate and could not air. However, the students disregarded the teacher's decision and "took it upon themselves to air the video" on a day that the teacher was out of the building. In this situation, she involved the students and the Assistant Principal where they talked about what happened. Because the students were insubordinate, they were suspended for a couple of days. Ironically, students did not seem to be negatively impacted by this action. According to the teacher, "When they came back to class, we resumed our normal classroom relationship. Seven years later, we still joke about this occurrence with each other on social media." In general, this teacher assumes that transgression is developmentally normal and that it is inherently part of the practice of video production pedagogy. 


\section{Bob's Perspective on Transgression}

Bob is a high school video production teacher from an East Coast upper-middle class suburban community with largely Caucasian students. Bob handles the topic of transgression right from the start of the semester, where he engages in a conversation at the beginning of each new semester by formally setting limits. He stresses the need for respect to peers and viewers in approaching the significant responsibility of producing quality content. He emphasizes the importance of developing professional respect for all members of a creative team. He identifies examples of inappropriate behaviors and he points to the school's student handbook to discuss issues of appropri ate attire and conduct. Students are discouraged from producing media that infringes copyright or "involves coarse language, drugs, violence, weapons, alcohol, or images that include inappropriate gestures."

In establishing the boundaries of acceptable and unacceptable content and student behavior, Bob serves as the executive producer role for the daily broadcast his students create. When students produce videos determined to be inappropriate, Bob grades their work using the project rubric. He explains to them what changes to the content need to be made for the video to appear on school news show and/or the website. Bob emphasized that creativity is an important skill for students to develop but that communication skills are even more important He wrote, "This truly has been an area of challenge for myself while working with students as they work on projects and try to be creative." Daily challenges include copyright infringement, social media, time management, and student attitudes towards the media class.

Bob sees how students are motivated by the desire to impress or please their peers; he notices that sometimes these efforts can be considered humorous at times and that sometimes "students think that viewers enjoy the content." The gap between the expectations of school culture and the expectations of contemporary popular culture are not immediately evident to students, as Bob explains:

Given they see this content and behavior on television and digital media its engrained into their culture, thus they don't consider it inappropriate. This is a challenge but generally students understand reasoning but occasionally they don't consider some of the content inappropriate. This translates into many classroom discussions as to what is considered inappropriate and to whom. I emphasize the need to respect student work and creativity as well as balancing the message translated or perceived by the viewing audience.

Notice that Bob sees that discussions about transgression as a worthwhile and meaningful learning experience. As a result, he has found that only rarely do students submit video content that is inappropriate. He explains, "I try to empower my students within our studio to make decisions within a live broadcast environment as they need to understand the responsibility they have to their school and community." With this responsibility comes accountability, however. When students make repeated mistakes, punishments are issues through a verbal warning or removal from the broadcast production for one to three days. "It is a difficult decision to make," Bob explains. However, "unfortunately some students do not understand reasoning or don't agree with decisions and decide to leave the production team."

\section{Louise's Perspective on Transgression}

Louise is a filmmaker and high school video production teacher at a public charter high school which serves largely working class and poor students including Caucasian,
African-American and Latino/a students on the East Coast of the United States. She has a broad and teacher-centric definition of "inappropriate behavior" as situations that disrupt the flow of instruction. For example, when she is demonstrating how to use editing software, she considers it inappropriate for students to engage in conversations with their peers. However, she appreciates that active learning is sometimes unruly, noting that if the class is screening a film and "students comment on the action out loud or quietly to their neighbor, this doesn't bother me." For some students, notes Louise, this is an indicator that they are engaged.

As a Causasian female teacher working with a heavily male population of African-American and Latino students, Louise feels it important to note that she has never been nor felt threatened by her students. But the number one issue is cell phone use, which is a substantial disruption to student learning. Louise asks "every single day" for students to put their cell phones away. "There are few moments when the phone is necessary to capture video, to look up stuff. Otherwise, it is non-stop continuous "passing of notes."'

Her students engage in audience behavior that may sometimes be considered transgressive. For example, when viewing film, her students have been known to stand up and applaud certain scenes. She has had situations where, when watching a film, students have burst out expletives in frustration, loudly and with anger, a behavior that she considers to be inappropriate. However, "heavy sighs and eye-rolling" is a behavior that she sees as "age appropriate, even if it is undesirable."

Unlike the other teachers in this study, Louise allows students to create videos in a wide range of genres, including narrative forms. In reflecting on inappropriate content in student videos, Louise tolerates the depiction of everyday life in ways that resonate with student lived experience and considers herself to be rather flexible. "Maybe too much so?" she wondered, demonstrating some metacognition on her educational practice in the context of the interview experience. She permits students to include "scenes of drinking (which was simulated-or so I was told), smoking (cigarettes and simulated pot-or so I was told), profanity, fights, cutting, suicide, and murder have all been depicted in student narrative films." She has also accepted the use of profanity in student videos, noting, "When they use the word " $@$ @ $k$, however, they are going for a gritty realism and I don't find this inappropriate."

Louise has accepted and encouraged student work that contradicts her own values and beliefs. For example, one student made a documentary on government conspiracies. As Louise notes, "It was pretty crazy, but she did a good job with production standards and research." During the screening of the video, Louise introduced it with the caveat that everyone has a right to their opinion and deserves our respect. She reminded students of the right to free speech. According to Louise, "This student was not very popular and quite marginalized due to her conservative beliefs and we wanted to protect her."

However, Louise has discovered some limits on the content that students produce when students refer to sexual practices. Her school administration has been involved in helping to establish them. She explains how a particular student transgression was handled:

No one has ever tried and I have never had to censor the following content that I would find inappropriate: sexualized nudity, story or dialog that wantonly infringes on the rights of others or is otherwise insensitive to any person or groups. We did have to censor a student who, being a teenager, thought provoking the establishment (us grown-ups) with references 
to blow jobs would be way cool. It was fine for his Capstone film, but my principal asked these references be removed for the final awards presentation due to children being in the audience.

Louise recognizes that some students intentionally transgress in order to provoke adults. "Without a doubt," she explains, "they do it to test boundaries. They want a reaction from the adults. In their estimation, it ups their 'cool' with their peers." On one occasion, she tried to dissuade a student from including PTSD (as suffered by a character depicted as a spy) as the focus of a humorous spoof by suggesting that might not go over well with the audience. "I let him know it was ultimately his decision," she explained.

By continuously reflecting on what works and what doesn't work, she tries to improve the class. Louise is aware that students' inappropriate behavior often comes from frustration and poor communication, noting, "We need to be mindful of what we demand from our students and how we communicate expectations." She emphasizes that film production is a creative subject, where "every assignment directly pertains to the final project (the making of a film) and is also plugged in to some part of the creative process." She teaches a bit of film history in order to support the creative process, noting that "the history of any art form provides a model of problem solving that can spark student creativity. That being said, it's sometimes a tough sell!" She values personal one-to-one engagement with students, believing that knowing each other increases the chance of positive outcomes. She tries to resist the tendency to judge students. In the end, however, Louise notes, "People are messy and unpredictable. And sometimes inappropriate." For Louise, transgression reflects students' lived experience and their depiction of it is all part of the creative process.

\section{James's Perspective on Transgression}

A filmmaker and media literacy scholar, James is in his first year teaching high school video production an alternative high school in a large city in the Mid-Atlantic region of the United States, with predominantly African-American students from poor and working-class families. Behaviors like cursing, talking over other students, and trying to disengage from the room, pulling away to the back or the corner do occur in his classroom. But James has a high threshold for "inappropriate" behavior and tries to understand the context in which the behavior is happening. To address these issues, he uses a collaborative problem-solving model to try to work with students who have outbursts in class, seem angry or frustrated, or aren't doing their work.

Some students create media that reflects their interest in the transgressive mass media they use at home. One of James' students did a final project on the American Horror Story series, which features sexual violence, gore, and serial murder. In analyzing the show, the student was mostly recapping the plot lines. James tried to push her to explain why she thought the storylines were so effective in entertaining or frightening in the first place. He explained:

With a little digging, she came up with different ideas for why the material she was using seemed so 'wrong' -- for instance, she came to the idea that clowns are 'too much' -- they push beyond mere entertainment and suggest something more sinister. I think that pushing students to analyze why the media they 'imitate' might seem to be transgressive can have a lot of value, but I'm not sure if that does anything to stop the impulse that students have to imitate it, nor am I sure that such analysis should stop imitation. Imitation is a crucial part of learning, and to "learn" popular culture forms, you need to be able to imitate them.

Allowing students wide latitude in creative expression may be part of a systematic strategy of learner engagement. Because his students have had a variety of generally negative experiences with school, James tries to give them "as much leeway as possible when making creative work." James explains:

I nudge them toward positive topics and socially beneficial ways to create fiction and non-fiction work, but I'm also pleased when they complete a project that's more "for them," including what I think a lot of educators might consider "inappropriate" -- creating songs (or using songs or videos) with cursing, glorification of drugs and violence, etc. For instance, a student might use an explicit song or video to talk about how much they like the song, without providing any particular critique of the content. Or they might create a song or rap that employs "inappropriate" material.

Many forms of student transgression result from simple imitation of the most popular forms of mass media. James believes that students don't aim to transgress when they use or imitate popular culture. Popular culture itself is transgressive, James notes, writing, "With the population of students I work with, these materials come from the everyday culture of their neighborhoods -- e.g., underground local rappers whom students may know themselves; videos and memes that are popular within their communities; etc." James sees imitation as a necessary part of learning to create digital media and it helps students to understand how media production actually works.

When video is used to depict one's lived experience, it may be transgressive, but James is sensitive to the significant gap between "personal media" and "professional media" when it comes to video creation. Comparing the gap between the personal and the professional, James redefines Masterman's (1985) "technicist trap" as a "technicist gap," acknowledging the many video production skills that separate amateur from professional production. Learning these conventions may even "distract" from more meaningful learning. As James explains:

When I've asked students to do more documentary work, I often find that even though the content of their work is more appropriate and more valued by other educators, their takeaway skills don't quite get them to the kinds of production they envision from popular culture. It's like they're learning their "home" language but in a dialect they can't actually use anywhere else.

James gives students wide berth to express themselves and he tries to make the classroom a safe space to create any content within a pretty broad zone of appropriateness. He recognizes that, "in the media classroom I get a pretty raw look at the whole gamut of what I would consider wildly transgressive material." He's not yet been confronted with the production of pornography, fight videos, or other clearly off-limits material from the perspective of the school administration. He suspects that actually students are very clear about the types of material that are "absolutely off-limits." He suspects that students generally "will transgress within the accepted norms of the school or classroom."

Because James is a Caucasian teaching largely African-American youth, he is aware that his own sense of inappropriateness should have a component of "understanding where they're coming from." Because they are used to hard-and-fast rules about swearing in schools, for example, many of his students are surprised to learn that in some productions, James thinks it's acceptable for them to use curse words.

Video production can be a highly personal form of expression, enabling transgression to enter through the depiction of everyday experience. James is aware of the gap between how students conceptualize inappropriate media 
content in relation to school assignments and the "more personal spaces that seep into the classroom from the periphery -- Twitter feeds with borderline-pornographic content; sexually explicit music videos; fight videos; drug use." James wishes that students would channel the energy they have for this personal media, which can often feel like a "third rail" in the classroom, into creative projects.

Discussion of transgression is most likely to occur in James' classroom when student work moves beyond the classroom to reach real audiences. Because his students are between the ages of 14 and 19, the real conversation about appropriateness happens when it comes time to distribute student work. James describes an occasion when a student who created a photo meme with inappropriate language wanted to display it on the front board of the classroom. James informed her, "Even though it was OK for her to make this image, I wouldn't display it in front of the classroom."

\section{Discussion}

\section{Transgression in the Context of Novice Expectations}

Transgression happens when beginners are socialized into a learning community. Human development scholars have also articulated the pleasures of transgression as a part of growing up. When creating videos outside of school, some researchers have found that children enjoyed transgression for its own sake. For example, in one study of children making videos at home, siblings repeatedly watched video clips they had recorded of themselves, including "transgressive moments of their gender play" as girls dressed like boys and boys dressed like girls. They enjoyed reviewing their humorous acting mistakes and bloopers. In doing so, researchers suggest that children gained awareness of how self-representations are constructed and how images function as a tool for projecting identity (Ivashkevich \& Shoppell 2013). Perhaps young media makers become absorbed in the "magic circle" of creative play, which is "never imposed by physical necessity or moral duty" (Huizinga and Hull 1949, 8).

Teachers in in this study acknowledged the normality and innocence of transgression. Rather than seeing it as anathema to learning, they embrace it as a natural part of the learning process. Susanne and Louise, in particular, recognize how students experience frustration and anxiety with the novelty of the media production process and the gap between their visions for their projects and what can realistically be achieved. Recall how, in this study, Susanne noted that her students may transgress simply in order to have the freedom of movement to walk through the hall without a hall pass. Her charitable understanding of her students as young and inexperienced enables her to see transgression as relatively harmless and creates space for them to learn by making mistakes.

However, the balance between creative freedom and creative control is not always easy for teachers to navigate, and their negotiations with students does not always lead to a productive learning experience. For example, Saxton (2007) studied a high school in Utah where each student was to create a three-minute narrative film over an eightweek period. Even with lengthy pre-production instruction on visual vocabulary and technique, the project was designed to require the students to spend most of the actual production time (the actual shooting and editing of the film) outside of class, using cell phones along with Windows Movie Maker or iMovie. Although absenteeism and tardiness decreased as students developed elaborate ideas about their creative video productions, many students had unrealistic and grandiose plans for their films, seeking to incorporate weapons into their story lines, for example. One student developed a story line with a graphic rape and murder; another developed a public service announcement that suggested that suicide could be a way to solve problems. Unfortunately, as the teacher admonished them to respect boundaries of school appropriateness, this was perceived as a "denial of freedom" that "took some of the pleasure out of the experience," as students who had to change their plans were less enthusiastic about their new ideas. During the filming process, students journals were full of frustrating venting, causing one student to write, "Screw this! I'll just take the zero!" (Saxton, 2007, 61).

\section{Transgression as Playing to Peer Audiences}

In this study, we have seen how, when students create media, they balance an interest in appealing to their peers with an interest in satisfying the expectations of the teacher. Students in Bob's class seem to have a good understanding of his academic expectations and his professional approach leads them to discuss whether a particular piece of content is "appropriate" for a particular target audience. Susanne struggled with student transgression when they aired an inappropriate video segment on the school news program even when she explicitly told them the piece was not to air: in this case, it was more important for them to impress their peers than it was to impress their teacher.

This evidence parallels a finding from a case study that reported transgressive behavior when comparing students' media production in and out of school, Tripp and Stephenson (2009) describe two working-class Latino middle-school students engaged with media at home and in a yearlong media production curriculum at school. At school, students worked on eight different media projects including creating PowerPoint presentations and digital videos. As special education students, these media production assignments offered new opportunities for them to create media as a way to learn. The students claimed these assignments were "more fun" and "better" than other types of schoolwork, but of course it was something they 'had to do,' much like other schoolwork. Researchers saw children's attempt to incorporate humor and popular culture into their work as a means to bridge the "disconnect between school media production assignments and the sense of enthusiasm students had for media culture." They describe the sheer delight of the students who, in reflecting on their work, described their use of South Park reference humor as their favorite part of the video. From their point of view, this humor was designed for their friends to enjoy. Because teachers had determined both the form and content of projects, "slipping popular culture references into projects can be seen as an effort (albeit a small one) on the part of students to make the media projects their own." The researchers note, "This small act of subverting the adult agenda and discourses involved in the project was important to some students" (Tripp \& Stephenson, 2009, 1198).

As we have seen in this study, when media production occurs in school, students sometimes struggle to negotiate the interests of the peer group and the academic expectations of the assignment (Buckingham, 2003; Buckingham \& Sefton-Green, 1994). Some students "walk a difficult line between 'following school rules' and 'playing to the gallery,' that is, to the peer audience" (Buckingham, 2003, 136). In one study of students in a writing class, teachers report that digital and multimedia tools for writing and composition can often inspire students to act out in the classroom in ways that express their fragile identity positions. In one case, a student called attention to herself through the media composition activities, "making exaggerated pronouncements through the activities using to elicit laughs or gasps, occasionally with sexual allusion, in- 
nuendo, or other inappropriate content" (Hines, Kersulov, Rowland \& Rupert, R. 2014, 487). In an interview, the student reported enjoying the expressive and performative dimensions of the project, but "resisted the turn to serious discussion reflecting on the activities." The authors point to the challenge teachers face as they work to enable productive practices with digital media, establishing a connection between the academic objectives of the assignment and issues of students' social identity.

Scholars such as Sholle and Denski (1994) spelled out this underlying bait-and -switch issue in the context of media education. In their book, Media Education and the (Re)production of Culture, they examined how media educators may exploit students' media interests to persuade them to use and apply academic concepts-- when what they really want to do is work and play with pop culture and their imagined media identities. As this study has shown, experienced video production teachers recognize that transgression is bound up with the reproduction and recirculation of mass media and popular culture and the inevitable tension between play and learning.

The results from this small study may make you wonder: are students more or less likely to transgress when they experience creative control or creative freedom within an assignment or class structure? Evidence from this study suggests that a context of clear expectations and norms may be associated with fewer transgressions, or at least, more mindful or purposeful or critical expressions of transgression. But it is not clear from this study whether or how transgression may support or inhibit student learning.

Table 1. Creative Control and Creative Freedom in the Media Production Classroom

\begin{tabular}{|c|c|c|}
\hline & Creative Control & Creative Freedom \\
\hline \multirow[t]{4}{*}{ Content } & $\begin{array}{l}\text { Specifying the topic, } \\
\text { issue or subject of the } \\
\text { production }\end{array}$ & $\begin{array}{l}\text { Allowing learners to } \\
\text { select the topic, content } \\
\text { or issue }\end{array}$ \\
\hline & $\begin{array}{l}\text { Specifying the use of } \\
\text { informational content } \\
\text { and sources }\end{array}$ & $\begin{array}{l}\text { Expecting learners to } \\
\text { freely choose infor- } \\
\text { mational content and } \\
\text { source materials }\end{array}$ \\
\hline & $\begin{array}{l}\text { Prohibiting the use } \\
\text { of remix copyrighted } \\
\text { materials }\end{array}$ & $\begin{array}{l}\text { Permitting the use } \\
\text { of remix copyrighted } \\
\text { materials }\end{array}$ \\
\hline & $\begin{array}{l}\text { Establishing expecta- } \\
\text { tions about appropri- } \\
\text { ate language }\end{array}$ & $\begin{array}{c}\text { Expectations about lan- } \\
\text { guage are not explicitly } \\
\text { presented }\end{array}$ \\
\hline \multirow[t]{2}{*}{ Format } & $\begin{array}{l}\text { Specifying the genre, } \\
\text { length or medium of } \\
\text { the production }\end{array}$ & $\begin{array}{c}\text { Offering learners a } \\
\text { choice of genre, length } \\
\text { or medium }\end{array}$ \\
\hline & $\begin{array}{l}\text { Requiring elements } \\
\text { like title and produc- } \\
\text { tion credits }\end{array}$ & $\begin{array}{l}\text { No title or credits re- } \\
\text { quirements specified }\end{array}$ \\
\hline \multirow[t]{3}{*}{ Process } & $\begin{array}{l}\text { Setting firm deadlines } \\
\text { for work to be com- } \\
\text { pleted }\end{array}$ & $\begin{array}{l}\text { Learners establish their } \\
\text { own deadlines }\end{array}$ \\
\hline & $\begin{array}{l}\text { Establishing expecta- } \\
\text { tions for individual or } \\
\text { collaborative work }\end{array}$ & $\begin{array}{c}\text { Choice to work } \\
\text { independently or as a } \\
\text { member of a team }\end{array}$ \\
\hline & $\begin{array}{l}\text { Requiring the use of } \\
\text { particular equipment, } \\
\text { software or technolo- } \\
\text { gy tools }\end{array}$ & $\begin{array}{c}\text { Student free choice of } \\
\text { equipment, software } \\
\text { and tech }\end{array}$ \\
\hline \multirow[t]{3}{*}{ Distribution } & $\begin{array}{c}\text { Production is expected } \\
\text { to be viewed by an } \\
\text { audience }\end{array}$ & $\begin{array}{l}\text { Learners choose } \\
\text { whether to share with } \\
\text { an audience }\end{array}$ \\
\hline & $\begin{array}{l}\text { Target audience is } \\
\text { determined by the } \\
\text { teacher }\end{array}$ & $\begin{array}{l}\text { Learners determine the } \\
\text { target audience }\end{array}$ \\
\hline & $\begin{array}{l}\text { Teacher distributes on } \\
\text { behalf of learner }\end{array}$ & Learner self-distributes \\
\hline
\end{tabular}

Creative control is the mechanism by which educators design learning experiences to meet specific outcomes or educational goals. Creative freedom is the means by which students experience true authorship. This study suggests that a balance of creative freedom and creative control may be needed in the design of video production learning experiences for high school students. As revealed in the cases, teachers may specify details of the content, format, production process and distribution of the work that students create. Table 1 depicts these four forms of creative control and freedom. Teachers may offer more or less guidance on the content of media productions, insisting that they be informative or academic in nature or encourage students to tell fictional or true stories. In establishing a learning process, teachers may set a deadline that the work must be completed within a week, but at the same time they may permit students a lot of flexibility with the format, giving students the ability to select the genre. They may control the distribution of student work, by emphasizing its publication on the school network or on the school website. Others may enable students to control the distribution of their own creative work. Through the design of learning experiences with a mix of creative freedom and creative control, video production teachers essentially negotiate with students about where, how and when transgression may occur in the context of their work.

\section{Transgression as a Response to Creative Control}

This study is this first to document how teachers themselves experience student transgression as an essential dimension of the continuum of creative freedom and creative control which is present in every learning experience. This work adds value to the voluminous literature on learners' experiences with informal production-based learning with digital media (Ito et al, 2009).

All the teachers in this study use a mix of opportunities for creative freedom and all frame up or shape learning experiences using forms of creative control. Some emphasized more professional routines of making media while others emphasized expressive and creative forms of media-making. Teachers interviewed for this study describe students who included in their video productions the lewd, the rude and the offensive simply as a part of their creative play, reflecting the freedom that is part of the creative process. Undoubtedly, transgression as a dimension of creative freedom has long been tied to innovation in culture, business and the arts. More recently, the richness in American culture has been attributed to the First Amendment's creation of unrestrained critical discourse (Batra, 2013).

Learning requires a careful balance of creative freedom and creative control in order to produce autonomy on the part of learners (Masterman, 1985). In navigating the dialectic between creative freedom and creative control, there is a key role for educators. In Lange's (2014) study of young YouTube producers, she discovered that, in creating video, young people were sometimes oblivious to the moral and ethical dimensions of their creative work. In capturing representations of subjects in front of the camera, she found many examples of young media makers depicting behaviors such as passing gas or picking noses, tantrums and physical violence. Lange describes how adolescents who created YouTube videos depicted real or dramatized altered states, following in the footsteps of the viral video, "David After Dentist" without an appreciation of the potential consequences and variety of potential interpretations that may be made. (2016, p. 167).

Sadly, some educators believe that creative freedom must be sacrificed in order to meet educational goals. Some of the teachers interviewed in this study offered substantial limits to student creative freedom with this 
justification in mind. However, in the paradigm of youth media, understanding the dialectic of creative freedom and creative control may help appreciate the complex relationships that develop between youth and their digital media mentors which may occur in or out of school ( Halverson, Lowenhaupt, Gibbons \& Bass, 2009). For example, in Young's (2012) study of youth media organizations in Philadelphia, she analyzed how the participatory practices activated competencies that were aligned with Common Core State Standards, recognizing that youth activism is compatible with the desired outcomes of formal education.

Because media educators work closely with youth to develop ideas, it may be that a "pedagogy of collegiality" develops as teachers and learners co-produce media work in ways that transcend traditional power relationships. In Drop that Knowledge, Soep and Chavez (2010) describe the features of this pedagogical approach as including joint framing, youth-led inquiry, mediated intervention, and distributed accountability. But it's also possible that in some cases, this sort of collegiality may become a pedagogy of adult hegemony, where learners get inducted into a particular (and controlling) discourse of prosocial or activist media making. Students are empowered here in the sense of occupying an identity position of greater social-political capital that does not overtly debase their primary discursive identities, but these instructional practices may still reproduce traditional power relationships of apprenticeship. To be successful, students must adopt identities preferred by the educators or artists, and though these are perhaps not like traditional educational power relationships, they are a form of creative control which imposes a critical perspective and process. Because youth media professionals spend "extraordinary amounts of time and resources to identify and develop relevant storylines for their productions," there is a common tendency for adult discourses to be reproduced in youth-produced media (Hauge 2014, 473). This may be especially ironic given that youth media productions are particularly designed to support youth voice and self-expression (Tyner, 2009).

It's worth wondering whether transgression as a form of creative expression is more or less likely to occur in contexts where student media production relies on a deep partnership between an adult educator, media artist or activist and a group of students (Goodman, 2003). Youth media instructors carefully scaffold a media production learning experience, beginning with pre-production processes to discover a message, develop a form, and usually create messages with some sort of social relevance. However, in Bach's (2010) study of a youth media organization in New York City, some resistance among youth participants was evident as they were involved in creating non-commercial public media to be broadcast to a wider audience. Although mentors wanted youth to create socially useful videos addressing political and social issues, participating youth appreciated the unrestricted communal space in youth media organizations and valued media education "primarily for its private utility - namely, the possibilities for career development and advancement it provides - rather than for its potential to contribute to a community knowledge base and serve a larger public aim" $(2010$, p. 1). Because youth voice itself was not critically examined, Bach found that young people occasionally created media texts that "reproduce sexist, homophobic, and other marginalizing perspectives, as youth themselves have grown up in a society wrought with these prejudices and are shaped by the institutions, social histories, and interactions they share with adults" (1).

Transgression, thus, may be the result of student awareness of the dialectic of creative freedom and creative control. For this reason, in handling learners' transgressive behavior and media content, teachers may need to show significant levels of sensitivity to both the learners and the learning context. In designing their assignments, they make flexible use of four forms of creative control to accomplish their pedagogical goals. Learners themselves can gradually develop creative control over content, format, process, and distribution.

In reviewing the literature on art education, Duncum (2007) notes that during the heyday of the creative self-expression movement, although educators emphasized the genuine freedom to explore and express as they pleased, proponents of creative self-expression were actually highly directive in their pedagogy. By the 1980s, art educators moved away from a focus on creative expression and instead emphasized Discipline Based Art Education, emphasized systematic acquisition of well-established fine arts skills and knowledge (Duncum, 2007). As a result, in many art classrooms in both public and private schools, art that connects to students' lived experience with popular culture is actively discouraged from the art classroom. For this reason, art teachers may ignore student transgression when it occurs, or fail to mention it when reporting on their teaching of popular culture. Indeed, Duncum appreciates the work of media literacy educators who have enabled students to use their interest in mass media and popular culture in ways that art educators have not.

On the ubiquitous reality of transgression in the context of youth media production, it is likely that the perspectives of experienced video production teachers may enable the framing of transgression as something to be welcomed, not feared. This approach should have value to classroom teachers across the K-12 and university contexts and may enable teachers and learners to see the negotiation of power relationships as a means for genuine co-learning opportunities to occur.

\section{Limitations}

This study also speaks to the need for youth media organizations to include a critical and reflective component to media education programs. Among the many challenges of teaching young people to produce media in an increasingly market-oriented, privatized, and commercial world is the negotiation of content, format, process and distribution issues always at play in the creative video production process.

Today, nearly every teacher can be a media production teacher, as free and low-cost video editing puts the power of video production into the hands of even the youngest children. As a result, more teachers will need to gain an understanding of transgression as matter of negotiating power. When transgression is welcomed, it provides considerable opportunities for authentic learning and personal growth. When it is feared, it inevitably reflects particular ideas about professionalization, job security and the power of social norms. When transgression is treated as a teachable moment and as a learning opportunity, it may provide instructors with insight on their own instructional strengths and weaknesses. Reflecting on how various assignments include a mix of creative freedom and creative control may help advance student understanding of concepts like format and target audience. More importantly, it may help educators and scholars revisit the social norms that exist in classrooms and how our interpersonal, institutional, and cultural expectations about classroom behavior shape, focus and direct the learning experience. 


\section{Refences}

Alvermann, D. E., Moon, J., \& Hagood, M. C. (1999). Popular culture in the classroom: Teaching and researching critical media literacy. Newark, DE: International Reading Association.

Bach, A. (2010). Youth media literacy practices: The possibilities and complexities of creating and distributing non-commercial public media in a private and commercial world. Dissertation. University of Pennsylvania Graduate School of Education.

Batra, N. (2013). The first freedoms and America's culture of innovation. Lanham, MD: Rowman and Littlejohn.

Bennett, W. L. (2008). Civic life online: Learning how digital media can engage youth. MIT Press.

Bhaskar, R., (1975 [1997]), A realist theory of science. 2nd edition. London, Verso.

Buckingham, D. (2013). Media education: Literacy, learning and contemporary culture. London: Polity Press.

Buckingham, David. Teaching popular culture: Beyond radical pedagogy. Psychology Press, 1998.

Buckingham, D., \& Sefton-Green, J. (1994). Cultural studies goes to school: Reading and teaching popular media. London: Taylor \& Francis.

Buckingham, D., Banaji, S., Burn, A., Carr, D., Cranmer, S., \& Willett, R. (2005). The media literacy of children and young people: A review of the research literature on behalf of Ofcom. Retrieved June 11, 2006 from http://www.ofcom.org.uk/advice/media_literacy/medlitpub/medlitpubrss/ml_children.pdf

Buckingham, D., \& Willett R. (2013). Digital generations: Children, young people, and the new media. New York: Routledge.

Darts, D. (2004). Visual culture jam: Art, pedagogy, and creative resistance. Studies in Art Education, 45(4), 313-327.

Darts, D. (2006). Head game\$: Engaging popular vi\$ual culture. In P. Duncum (Ed.), Visual culture in the art class: Case studies (pp. 99-198). Reston, VA: National Art Education Association.

Duncum, P. (2009). Toward a playful pedagogy: Popular culture and the pleasures of transgression. Studies in Art Education, 232-244.

Duncum, P. (2007). What we are learning about teaching popular visual culture. In M. A. Park (Ed.), Art education as critical cultural inquiry (pp. 216-233). Seoul, Korea: Mijlnsa.

Edwards, R. \& Holland, J. 2013. What is qualitative interviewing? New York: Bloomsbury.

Goodman, S. (2003). Teaching youth media: A critical guide to literacy, video production \& social change. New York: Teachers College.

Halverson, E. R., Lowenhaupt, R., Gibbons, D., \& Bass, M. (2009). Conceptualizing identity in youth media arts organizations: A comparative case study. E-Learning and Digital Media, 6(1), 23-42.

Hines, M., Kersulov, M., Rowland, L. \& Rupert, R. 2014. Composing texts and identities in an alternative high school English class. In R. Anderson, Ed. Handbook of Research on Digital Tools for Writing Instruction in K-12 Settings (479 - 498). New York: IGI .
Huizinga, J., Hull, R., \& Carrington F. (1949). Homo ludens: A study of the play-element in culture. Translated by RFC Hull. London: Routledge \& Kegan Paul.

Hrabowski, F. \& Sanders, M. (2015). Increasing teacher diversity in the teacher workforce: One university's approach. Thought and Action, Winter, $101-116$.

Ito, Mizuko, et al. (2013). Connected learning: An agenda for research and design. Digital Media and Learning Research Hub.

Ito, M., et al. (2009). Hanging out, messing around, and geeking out: Kids living and learning with new media. Cambridge: MIT.

Ivashkevich, O. , \& Shoppell, S. (2013). Appropriation, parody, gender play and self -representation in preadolescents' digital video production. International Journal of Education \& the Arts, 134(2), 1-24.

Jenkins, H., et al. (2009). Confronting the challenges of participatory culture: Media education for the 21st century. Cambridge MA: MIT Press.

Kenway, J., \& Bullen, E. (2001). Consuming children: Education, entertainment, advertising. London: Open University Press.

Lange, P. G. (2014). Kids on YouTube: Technical identities and digital literacies. Left Coast Press.

Marsh, J. (2005). Popular culture, new media and digital literacy in early childhood. New York: Psychology Press.

Masterman, L. (1985). Teaching the media. New York: Routledge.

Saxton, B. N. (2007). The Media Production Experience: a Phenomenological Study of Student Media Production in a Secondary Education Environment. Brigham Young University, MA thesis, paper 1014. Retrived from http://scholarsarchive.byu.edu/cgi/ viewcontent. .cgi?article $=2013 \&$ context $=$ etd

Tripp, L. M. and Herr-Stephenson, R. (2009), Making access meaningful: Latino young people using digital media at home and at school. Journal of Computer-Mediated Communication, 14: 1190-1207. doi: 10.1111/j.1083-6101.2009.01486.x

Tyner, K. (2009). Media literacy: New agendas in communication. New York: Routledge.

Young, J. S. (2012). Linking learning: Connecting traditional and media literacies in 21 st century learning. Journal of Media Literacy Education, 4(1), 70-81. 